\title{
Chemical composition of carrot seeds (Daucus carota L.) cultivated in Turkey: characterization of the seed oil and essential oil
}

\author{
By Mehmet Musa Özcan ${ }^{1 *}$ and Jean Claude Chalchat ${ }^{2}$ \\ ${ }^{1 *}$ Department of Food Engineering, Faculty of Agriculture, Selçuk University, 42031 Konya,Turkey. \\ e-mail: mozcan@selcuk.edu.tr \\ ${ }^{2}$ Universite Blaise Pascal de Clermont, Laboratoire de Chimie des Huiles Essentielle, \\ 63177 Aubiere Cedex, France.
}

\section{RESUMEN}

Composición química de semillas de zanahoria (Daucus carota L.) cultivadas en Turquía: caracterización del aceite de semilla y del aceite esencial.

Se determinó la composición química y las propiedades físicas de las semillas de zanahoria (Daucus carota L.) obtenidas en Konya, Turquía, con objeto de investigar usos potenciales de las mismas. Se determinó la humedad, el peso, el contenido proteico, en aceite, en fibra, en ceniza, en ceniza insoluble en ácido clorhídrico, los carbohidratos totales, y el rendimiento de la obtención de aceite esencial a partir de 1000 semillas maduras. Asimismo se determinó la densidad relativa, el índice de refracción, el contenido en ácidos grasos libres, el índice de peróxidos, el índice de yodo, el índice de saponificación y el insaponificable del aceite de la semilla. Los principales ácidos grasos determinados por cromatografía gaseosa fueron petroselénico $(59.35 \%)$, linoleico $(11.82 \%)$, palmítico (10.01\%), y esteárico $(2.41 \%)$. El contenido mineral (Al, $\mathrm{Ca}, \mathrm{Cu}, \mathrm{Fe}, \mathrm{K}, \mathrm{Li}, \mathrm{Mg}, \mathrm{Mn}, \mathrm{Na}, \mathrm{Ni}, \mathrm{P}$ $\mathrm{Se}, \mathrm{Sr}, \mathrm{V}$ and $\mathrm{Zn}$ ) de la semillas fue determinado por espectroscopia de emisión de atómica (ICP-AES). Las semillas resultaron ser ricas en proteína, fibra y ceniza. Las composiciones del aceite esencial y del aceite comestible fueron determinadas por GC y GC-MS. Los rendimientos de aceite esencial y comestible fueron 0.83 y $7.84 \%$, respectivamente. Los constituyentes mayoritarios del aceites esencial fueron carotol $(66.78 \%)$, dauceno $(8.74 \%),(Z, Z)-\alpha$-farneseno $(5.86 \%)$, germacreno D $(2.34 \%)$, trans- $\alpha$-bergamoteno $(2.41 \%)$, y $\beta$-selineno $(2.20 \%)$. Por su parte, carotol (30.55\%), ducol $(12.60 \%)$ y capaenol $(0.62 \%)$ fueron los componentes principales del aceite comestible.

PALABRAS-CLAVE: Aceite esencial - Apiaceae - Composición - Ducus carota L. - Minerales - Semilla de zanahoria.

\section{SUMMARY}

Chemical composition of carrot seeds (Daucus carota L.) cultivated in Turkey: characterization of the seed oil and essential oil.

Chemical composition and physical properties were established in carrot (Daucus carota L.) seeds from Konya, Turkey to investigate their potential uses. Mature seeds were evaluated for moisture, crude protein, crude oil, crude fiber, ash, $\mathrm{HCl}$-insoluble ash, total carbohydrate, essential oil yield and weight of 1000 seeds. Also, relative density, refractive index, free fatty acids, peroxide value, iodine value, saponification number and unsaponifiable matter were determined in the seed oil. The main fatty acids identified by gas chromatography were petroselinic $(59.35 \%)$, linoleic $(11,82 \%)$, palmitic $(10.01 \%)$ and stearic $(2.41 \%)$ acids. Mineral contents (Al, $\mathrm{Ca}, \mathrm{Cu}, \mathrm{Fe}, \mathrm{K}, \mathrm{Li}, \mathrm{Mg}, \mathrm{Mn}, \mathrm{Na}, \mathrm{Ni}, \mathrm{P}, \mathrm{Se}$, $\mathrm{Sr}, \mathrm{V}$ and $\mathrm{Zn}$ ) of seeds were also determined by Inductively Coupled Plasma Atomic Emission Spectrometry (ICP-AES). The seeds were found to be rich in protein, fiber and ash.

The essential oil and edible oil compositions of carrot seeds from Konya were investigated by GC and GC-MS. The oil yields of essential and edible oil from carrot seeds were established as $0.83 \%$ and $7.84 \%$, respectively. The major constituents of seed essential oil were carotol $(66.78 \%)$, daucene $(8.74) \%,(Z, Z)$ - $\alpha$-farnesene $(5.86 \%)$, germacrene D $(2.34 \%)$, trans- $\alpha$-bergamotene $(2.41 \%)$ and $\beta$-selinene $(2.20 \%)$. Whereas, carotol $(30.55 \%)$, daucol $(12.60 \%)$ and copaenol $(0.62 \%)$ were the important components of edible carrot seed oil. However, the dominant component of both oils was carotol.

KEY-WORDS: Apiaceae - Carrot seed - Composition Daucus carota $L$ - Essential oil - Minerals.

\section{INTRODUCTION}

Carrot (D. carota L., Apiaceae) is one of the most commonly used vegetables for human nutrition. D.carota is called as "havuç tohumu", "yere geçen", "keşür" and "pörçüklü" in Turkish. It is a tall robust biennial spiny-fruited herb growing in dried-out fields or meadows. Carrots are cultivated worldwide. They are characterized by relatively moderate requirements for climate and soil. Owing to their modest needs for cultivation and storage, they can be sold fresh throughout the year (Baytop, 1984; Vogel, 1996; Fritz and Stolz, 1989; Schaller and Schnitzler, 2000; Schieber et al., 2001). Their juices and blends are among the most popular nonalcoholic beverages. A steady increase in carrot juice consumption has also been reported from other countries. It is regarded as a healthy food item because of its high vitamin and fiber content (Nilsson, 1987; Chen and Tang, 1998; Negi and Roy, 2000; Schieber et al., 2001; Gonny et al., 2004).

In the development of new oil seed crops interest has turned to the members of the Umbelliferae family. The yields per hectare (4-30 dt/ha) and oil content of these oil crops (8-24\%) are not extremely high. But these agricultural crops, which contain spice plants like caraway, celery, coriander, dill and 
parsley, are of interest due to their high amounts of petroselinic acid (Kleiman and Spencer,1982; Rühl, 1993; Hondelman, 1985; Schuster, 1992; Reiter et al., 1998a). Carrot seed essential oil is widely used for its numerous applications concerring the formulation of certain alcoholic liguors as well as aromatic and fragrance compositions. It contains about $0.5-1.6 \%(\mathrm{v} / \mathrm{w})$ essential oil. Its essential oil is used for medicinal purposes such as diuretic, stomachic (Baytop, 1984; Bauer et al., 1990; Lawrance 1992-1994; Mazzoni et al., 1999). The high intensity of harsh carrot-like flavor in fresh plant products is commonly considered to be genetically determined and has therefore been reduced by breeding in carrots. Nevertheless, unacceptable flavor can occur at the consumer level and this is connected with suboptimal postharvest storage conditions and harsh handling during distribution. In carrots, bitter and harsh as well as flat, insipid flavors have been described in response to ethylene exposure, mechanical stress or storage in low oxygen atmospheres (Simon, 1985; Lafuente et al., 1989; Seljasen et al., 2001; Seljasen et al., 2004). Various attempts were made at utilizing carrot pomace in food such as bread (Ohsawa et al., 1994), cake, dressing and pickles (Ohsawa et al., 1995), and for the production of functional drinks (Henn and Kunz, 1996; Schieber et al., 2001). Several studies on the chemical characterization of carrot seed and seed oil have been caried out (Mazzani et al.,1999; Gonny et al., 2004; Zlatanow, 1994; Seljasen et al., 2004; Lie Ken Jie et al., 1996; Ochocka and Lamparczyk, 1993; Parker et al., 2003).

Recently, one oil distilled from the blooming umbels of D.corota L. ssp. carota growing wild in Poland was characterized by a high content of monoterpene hydrocarbons (84\%), and the major components were $\alpha$-pinene $(41 \%)$ and sabinene (18\%) (Staniszewska and Kula, 2001). No detailed study on the physical properties, chemical composition, essential oil composition and mineral contents of the seeds of $D$. carota has been performed so far. The aim of this study was to establish physical and chemical properties of carrot seed and oil and chemical composition of essential and edible oil of the seed oil.

\section{MATERIAL AND METHODS}

\subsection{Material}

Carrot seeds were purchased locally from herbal and vegetable suppliers in Konya in Turkey in the year 2004. Carrot seeds were transported to the laboratory in glass jars and held at room temperature. They were cleaned in an air screen cleaner to remove all foreign matter such as dust, dirt, stones and chaff, and immature and broken seeds were discarded as well. Their moisture content was measured on arrival. Seeds were dried to a constant weight at room temperature for analyses. Prior to a chemical analysis, samples (about $300 \mathrm{~g}$ ) were ground to pass a $0.5 \mathrm{~mm}$ screen. Methyl esters of fatty acids (palmitic, palmitoleic, stearic, oleic, linoleic, petroselinic, arachidic, vaccenic) were purchased from Sigma Company. The solvents were used in p.a.quality.

\subsection{Oil extraction}

The oil was extracted from crushed seeds with petroleum ether $\left(50{ }^{\circ} \mathrm{C}\right)$ in a Soxhlet extractor. The extract was evaporated in a vacuum. The lipid extract was collected in a flask. The extracted lipid was weighed to determine the oil content and stored under nitrogen at $4{ }^{\circ} \mathrm{C}$ for further analysis.

\subsection{Recovery of essential oil}

Dried carrot seeds were ground into small pieces and subjected to hydrodistillation for $4 \mathrm{~h}$ using a Clevenger-type apparatus (Clevenger, 1928), and the oils obtained were dried over anhydrous sodium sulfate. Essential oil yield on a dry weight basis was $0.83 \%$.

\subsection{Physicochemical properties of seed and oil}

The weight of 1000 seeds was determined. The chemical and physical properties (moisture, crude protein, crude oil, crude fiber, crude energy, ash, $\mathrm{HCl}$-insoluble ash, relative density, refractive index, free fatty acids, peroxide value, saponification number and unsaponifiable matter) were analyzed according to AOAC $(1984,1990)$. The total amount of carbohydrate was found by subtracting the amount of ash protein and fat from total dry matter (Çağlarırmak, 2003).

\subsection{Determination of fatty acids}

Fatty acids were derived using the boron trifluoride method (Hışıl, 1988). The fatty acids were converted to their methyl esters by heating in $10 \%$ BF3-methanol (Küsmenoğlu et al., 1997). Commercial mixtures of fatty acid methyl esters were used as reference data for the relative retention times (AOCS, 1990). Results are given as mean values of two replicates.

\subsection{Determination of mineral contents}

About $0.5 \mathrm{~g}$ dried and ground carrot seed sample were put into a burning cup and $15 \mathrm{ml}$ pure $\mathrm{HNO}_{3}$ were added. The sample was incinerated in a MARS 5 Microvawe Oven at $200{ }^{\circ} \mathrm{C}$ and dissolved ash diluted to a certain volume with water. Three replications of incineration were made. Duration of incineration was 60 minute. Concentrations were determined with an Inductively Coupled Plasma Atomic Emission Spectrometry (ICP-AES) (Skujins, 1998). 


\section{Working conditions of ICP-AES:}

Mineral contents were established by an ICP. AES (Varian-Vista) Instrument. RF Power was 0.7-1.5 kw (1.2-1.3 kw for Axial). Plasma gas flow rate $(\mathrm{Ar})$ was $10.5-15 \mathrm{~L} / \mathrm{min}$. (radial) and $15 \mathrm{~L} / \mathrm{min}$. (axial). Auxiliary gas flow rate (Ar) was $1.5 \mathrm{~L} / \mathrm{min}$. Viewing height, copy and reading time and copy time were calibrated as 5-12 mm, 1-5 s (max. $60 \mathrm{~s}$ ) and $3 \mathrm{~s}$ (max. $100 \mathrm{~s}$ ), respectively.

\subsection{Identification of essential oil components}

For identification of components, analytical HP 5890 gas chromatograph equipped with FID (GC) was performed using a DELSI $121 \mathrm{C}$ apparatus fitted with a flame ionization detector and a CP WAX 51 fused silica column $(25 \mathrm{~m} \times 0.3 \mathrm{~mm} ; 0.25$ $\mathrm{mm}$ film thickness). Temperature was programmed from $50^{\circ} \mathrm{C}$ for $5 \mathrm{~min}$ and programmed to reach $220^{\circ} \mathrm{C}$ at the rate of $3^{\circ} \mathrm{C}$ per min. ACP WAX 51 fused silica WCOT column $(60 \mathrm{~m} \times 0.3 \mathrm{~mm})$ for GC/ MS was used with helium as carrier gas. For GC/MS a CPWAX 52 fused silica CB column $(50 \mathrm{~m}$ $\times 0.25 \mathrm{~mm}$ ) was used with helium as carrier gas (flow rate $1 \mathrm{ml} / \mathrm{min}$ ) and coupled to a HP mass spectrometer: ionization energy $70 \mathrm{eV}$. Temperature programming was from $50-240^{\circ} \mathrm{C}$ at the rate of $3^{\circ} \mathrm{C} / \mathrm{min}$. The samples were injected at injector temperature $240^{\circ} \mathrm{C}$. The components were identified by comparing linear Kovats indexes (KI), their retention times (RT) and mass spectra with those obtained from the authentic samples and/or the MS library.

The percentage composition of the essential oils was computed from $6 \mathrm{C}$ peak areas without correction factors. Qualitative analysis was based on a comparison of retention times and mass spectra with corresponding data in the literature (Adams, 2001).

\subsection{Statistical analysis}

Results were analyzed for statistical significance by analyses of variance (Püskülcü and İkiz, 1989). Analyses of variance and least significant difference tests were conducted to identify differences among means. Data were reported as mean \pm Standard deviation.

\section{RESULTS AND DISCUSSION}

The proximate properties of carrot seed are given in Table 1. The oil contents of all investigated specimens are constant, but differ considerably within the species: fennel $10.5-14.6 \%$, caraway $9.5-$ $14.3 \%$, coriander $9.2-16 \%$ (Reiter et al., 1998a). The crude protein, crude fiber, crude oil and crude ash contents of carrot seeds were higher than for terebinth fruits reported by Özcan (2004). The oil content of carrot seed was found lower compared
Table 1

Physical and chemical properties of carrot seed (dry matter basis; $\mathrm{n}: 3$ )

\begin{tabular}{lc}
\hline \multicolumn{1}{c}{ Property } & Value \\
\hline Moisture (\%) & $6.41^{\star} \pm 0.87^{* *}$ \\
Crude protein (Nx6.25) (\%) & $25.19 \pm 1.13$ \\
Crude oil (\%) & $7.89 \pm 0.68$ \\
Crude fibre (\%) & $31.99 \pm 2.21$ \\
Ash (\%) & $11.52 \pm 0.14$ \\
Total carbohydrate (\%) & $52.3 \pm 2.13$ \\
HCl insoluble ash (\%) & $0.0056 \pm 0.0012$ \\
Weight of 1000 seeds (g) & $2.68 \pm 0.18$ \\
Essential oil yield (\%) & $1.01 \pm 0.02$ \\
\hline
\end{tabular}

* mean

** Standard deviation

with caper seed oil (14.6\% - 39.0\%) determined by Akgül and Özcan (1999) and Matthaus and Özcan (2005). Results show that there are some differences compared with literature values. These differences can probably be due to different plant seed, soil characteristics and environmental factors.

The extracted oil was yellowish in color. Its physical and chemical characteristics are given in Table 2. The oil had a relative density of 0.9811 , lower than the value reported by Akgül and Özcan (1999) for caper oil (1.0840-1.1045). The unsaponifiable matter content was $9.3 \mathrm{~g} / \mathrm{kg}$, and this value is different than that of other terebinth fruit oil (Özcan, 2004), but higher than that of many seed oils, eg caper. The values were reported by Akgül and Özcan (1999). The peroxide and acidity values were $1,6 \mathrm{meq} / \mathrm{kg}$ and $5,6 \%$, respectively, lower than generally recommended for commercial edible crude vegetable oils $(<10)($ TSE, 1971).

The mineral contents of carrot seeds were determined by ICP-AES (Table 3). Seeds were found rich in $\mathrm{Ca}, \mathrm{P}, \mathrm{K}, \mathrm{Na}, \mathrm{Mg}$ and Al. Generally, mineral contents of carrot seeds were found lower compared with olive, banana and fig (Cemeroğlu and Acar, 1986) and terebinth fruit (Özcan, 2004). Also, K, $\mathrm{P}, \mathrm{Ca}$ and $\mathrm{Fe} \mathrm{Mg}, \mathrm{Al}, \mathrm{Na}$ concentrations were lower than those in caper seeds (Özcan, 2005).

The fatty acid composition of carrot seed oil was determined by gas chromatography (Table 4). Petroselinic acid (59.35\%) was present in the

Table 2

Physico-chemical properties of carrot seed oil $(n: 3)$

\begin{tabular}{lc}
\hline \multicolumn{1}{c}{ Property } & Value \\
\hline Relative density $\left(\mathrm{d}^{20} 20\right)$ & $0.9811^{*} \pm 0.0013^{\star *}$ \\
Refractive index $\left(\mathrm{n}^{20} \mathrm{D}\right)$ & $1.473 \pm 0.004$ \\
Acidity (oleic, $\%)$ & $5.60 \pm 1.13$ \\
Peroxide value $(\mathrm{meq} / \mathrm{kg})$ & $16.0 \pm 2.1$ \\
Saponification number & $143.6 \pm 12.7$ \\
Unsaponifiable matter $(\mathrm{g} / \mathrm{kg})$ & $9.3 \pm 1.2$ \\
${ }^{*}$ mean & \\
${ }^{* *}$ Standard deviation &
\end{tabular}


Table 3

Mineral contents of carrot seed (dry matter basis;n:3) (mg/kg)

\begin{tabular}{lc}
\hline \multicolumn{1}{c}{ Fatty acids } & Concentrations \\
\hline $\mathrm{Al}$ & $23.31^{\star} \pm 2.17^{\star *}$ \\
$\mathrm{~B}$ & $0.306 \pm 0.073$ \\
$\mathrm{Ca}$ & $164.11 \pm 31.02$ \\
$\mathrm{Cr}$ & $0.086 \pm 0.011$ \\
$\mathrm{Cu}$ & $0.06 \pm 0.01$ \\
$\mathrm{Fe}$ & $8.21 \pm 0.93$ \\
$\mathrm{~K}$ & $180.55 \pm 37.36$ \\
$\mathrm{Mg}$ & $15.48 \pm 1.61$ \\
$\mathrm{Mn}$ & $0.403 \pm 0.083$ \\
$\mathrm{Na}$ & $24.35 \pm 4.39$ \\
$\mathrm{Ni}$ & $0.059 \pm 0.008$ \\
$\mathrm{P}$ & $75.40 \pm 19.28$ \\
$\mathrm{Se}$ & $0.005 \pm 0.001$ \\
$\mathrm{~V}$ & $0.184 \pm 0.038$ \\
$\mathrm{Zn}$ & $0.281 \pm 0.061$ \\
\hline
\end{tabular}

* mean

** Standard deviation

Table 4

Fatty acid composition of carrot seed oil $(\mathrm{mg} / 100 \mathrm{~g})(\mathrm{n}: 3)$

\begin{tabular}{lc}
\hline \multicolumn{1}{c}{ Fatty acids } & Concentrations \\
\hline Palmitic (16:0) & $10.01^{\star} \pm 0.13^{\star *}$ \\
Palmitoleic (16:1) & $0.64 \pm 0.02$ \\
Stearic (18:0) & $2.41 \pm 0.06$ \\
Oleic (18:1) & $0.17 \pm 0.01$ \\
Linoleic (18:2) & $11.82 \pm 1.17$ \\
Petroselinic (18:1) (n-6) & $59.35 \pm 3.81$ \\
Vaccenic (18:1) $(\mathrm{n}-11)$ & $0.55 \pm 0.01$ \\
Arachidic (20:0) & $0.81 \pm 0.03$ \\
Unknown & 14.26 \\
\hline * mean & \\
** Standard deviation &
\end{tabular}

highest concentration, followed by linoleic (11.82\%), palmitic (10.01\%) and stearic (2.41\%). Palmitoleic, oleic and arachidic, gadoleic acids were present in minor amounts. Reiter et al. (1998a) found that the contents of the main fatty acids of seed oils of fennel varieties were 4.3-4.4\% palmitic, 0.9-1.4 \% stearic, 71.9-73.9 \% petroselinic, 4.6-5.3 $\%$ oleic and 0.3-0.4 \%vaccenic and 15.8-16.5\% linoleic avids. Seed oils of caraway (Carum carvi) varieties extracted with petroleum ether in a Soxhlet extractor contained about 4.0-4.7\% palmitic, 1.1$1.7 \%$ stearic, $33.5-42.7 \%$ petroselinic, $15.2-24.0 \%$ oleic and 34.8-36.5\% linoleic acid and had the lowest total saturated fatty acids among all tested oils (Reiter et al., 1998a). The same researchers (Reiter et al., 1998a) established 3.2-4.4\% palmitic, $0.6-1.1 \%$ stearic, $67.1-73.0 \%$ petroselinic, $8.1-9.2 \%$ oleic and $14.2-18.5 \%$ linoleic acid in coriander (Coriandrum sativum) seed oil. Cold pressed carrot seed oil contained about $82 \%$ oleic, $13.19 \%$ linoleic, $3.71 \%$ palmitic acid and had the lowest total saturated fatty acids among all tested oils
(Parker et al.,2003). The same researchers established $12.11 \%$ palmitic, $24.03 \%$ oleic, 55.82 $\%$ linoleic, $3.43 \%$ stearic acid in caraway seed oil. When petroselinic acid value was compared with the literature, it was found to be low. It seems possible that this oil was extracted from immature seeds. The extremely high value of petroselinic acid $(91 \%)$ obtained by Thies (1993) may be explained by an insufficient separation of methylthio derivatives of fatty acids, which does not allow an exact quantification (Reiter et al., 1998a). Petroselinic acid contents of caraway seed oil was found as $42.0 \%, 35.4 \%$ (Kleiman and Spencer, 1982) and 40.3\% (Gunstone,1991). Petroselinic acid $(71.8 \%)$ is the predominant acid of coriander seed oil (Griffithhs et.al.,1992). Reither et al. (1998b) determined 42.4 and $73.7 \%$ petroselinic, 15.2 and $4.8 \%$ oleic and 0.6 and $0.3 \%$ cis-vaccenic acid in caraway (C.carvi) and fennel (Foeniculum vulgare) seed oil, respectively. In general, oil plants (exept of genetically modified or breeded) are not able to accumulate more than $80 \%$ of one fatty acid due to oilcrop biochemistry (Murphy, 1993; Reiter et al., 1998a).

Carrot seed oil contains aproximately $70 \%$ petroselinic acid (cis-6-18:1) (Dutta and Appelqvist, 1989). Petroselinic acid is the predominant fatty acid in storage lipids of many members of the Apiaceae and has considerable industrial potential (Dutta, 1992). The fatty acid composition of vegetable oils is affected by growth conditions, harvest and postharvest (ilisulu, 1973).

The components identified in the essential oil of carrot seed and edible seed oil are listed in Table 5 in the order of their experimental Retention Indices (RI). The essential oil exhibited a light yellow color. The GC and GC-MS analyses of seed essential oil and seed oil resulted in the identification of 34 and 14 components, respectively. The major constituents of seed essential oil were carotol $(66.78 \%)$, daucene $(8.74 \%),(Z, Z)$ - $\alpha$-farnesene $(5.86 \%)$, germacrene D $(2.34 \%)$, trans- $\alpha-$ bergamotene $(2.41 \%), \beta$-selinene $(2.20 \%), \beta$ bisabolene (1.90\%), bicyclogermacrene (1.87\%) and $\beta$-caryophyllene (1.10\%) (Table 5). Carotol and $\beta$-caryophyllene comprised 49.51 and $47.99 \%$ of the seed extract, respectively (Jasicka-Misiak et al., 2002). Whereas, carotol (30.55\%), daucol (12.60\%) and copaenol $(0.62 \%)$ were the important components of edible carrot seed oil (Table 6). However, the dominant component of both oils was carotol.

Gonny et al., (2004) found that the Corsican oil of Daucus carota L. contained E-methylisoeugenol (33.0\%), $\alpha$-pinene (24.9\%) and elemicin (11.4\%) as its major components. As was reported previously (Mazzoni et al., 1999), trans-dauca-8,11diene,duaca-5,8-diene, acora-4,9-diene, acora-4,10diene, (E)- $\beta$-10,11-dihydro-10,11-epoxyfarnesene and $(E)$-methylisoeugenol were identified as the major components of Daucus carota seed oil. Geranyl acetate (51.74\%-76.95\%) was the major component of D.carota subsp.gummifer fruits (Pinilla 
Tabla 5

Chemical composition of carrot seed essential and edible oil

\begin{tabular}{|c|c|c|c|c|}
\hline RT & $\mathbf{R I}$ & Compounds & Essential oil (\%) & Edible oil (\%) \\
\hline 9.14 & 939 & $\alpha$-pinene & 0.67 & - \\
\hline 9.64 & 953 & Camphene & 0.04 & - \\
\hline 10.56 & 971 & Sabinene & 0.10 & - \\
\hline 10.64 & 980 & $\alpha$-pinene & 0.52 & - \\
\hline 11.21 & 991 & Myrcene & 0.17 & - \\
\hline 12.46 & 1031 & Limonene & 0.43 & - \\
\hline 14.42 & 1088 & Terpinolene & 0.08 & - \\
\hline 14.84 & 1098 & Linalool & 0.34 & 0.25 \\
\hline 14.93 & 1100 & n-nonanal & 0.05 & - \\
\hline 16.00 & 1139 & Trans-pinocarveol & 0.04 & - \\
\hline 16.20 & 1144 & Trans-verbenol & 0.08 & - \\
\hline 17.42 & 1180 & p-cymene-8-ol & 0.07 & - \\
\hline 17.59 & 1195 & $\alpha$-terpineol & 0.07 & - \\
\hline 18.09 & 1204 & Verbenone & 0.03 & - \\
\hline 19.08 & 1243 & Carvone & 0.03 & - \\
\hline 22.92 & 1380 & Daucene & 8.74 & 0.43 \\
\hline 23.71 & 1415 & Cis- $\alpha$-bergamotene & 0.13 & - \\
\hline 23.87 & 1418 & $\beta$-caryophyllene & 1.10 & - \\
\hline 24.02 & 1420 & Z- $\alpha$-farnesene & 0.19 & - \\
\hline 24.26 & 1435 & Trans- $\alpha$-bergamotene & 2.41 & 0.26 \\
\hline 24.3 & 1446 & E- $\beta$-farnesene & - & 0.47 \\
\hline 24.47 & 1449 & Epi- $\beta$-santalene & 0.15 & - \\
\hline 24.79 & 1461 & $(Z, Z)-\alpha$-farnesene & 5.86 & - \\
\hline 25.17 & 1480 & Germacrene D & 2.34 & 0.25 \\
\hline 25.39 & 1481 & Ar-curcumene & 0.23 & - \\
\hline 25.56 & 1490 & $\beta$-selinene & 2.20 & 0.47 \\
\hline 25.76 & 1498 & $\alpha$-selinene & 0.89 & 0.08 \\
\hline 25.86 & 1500 & Bicyclogermacrene & 1.87 & 0.61 \\
\hline 26.02 & 1506 & $\beta$-bisabolene & 1.90 & 0.35 \\
\hline 26.17 & 1515 & Z- $\gamma$-bisabolene & 0.05 & 0.18 \\
\hline 26.35 & 1523 & $\beta$-sesquiphellandrene & 0.46 & - \\
\hline 27.25 & 1563 & 15 copaenol & 0.26 & 0.62 \\
\hline 28.56 & 1595 & Carotol & 66.78 & 30.55 \\
\hline 29.10 & 1638 & Daucol & 0.45 & 12.60 \\
\hline 29.67 & 1671 & $\alpha$-eudesmol+alfa-cadinol & 0.21 & - \\
\hline 35.5 & 1957 & Oleic acid & - & 0.80 \\
\hline plam & & & 98.94 & 47.92 \\
\hline
\end{tabular}

et al.,1995). Also,the oil obtained from the air dried seed essential oil of D.carota contained $\alpha$ terpinolene, $\beta$-caryophyllene, $\alpha$-pinene, myrcene, $\alpha$ terpinene and limonene (Schaller and Schnitzler, 2000). Our results were generally different from the literature findings on the major components. These variations may be due to different climatological factors, the nutritional status of the plants, variety and other factors that can influence oil composition.

As a result, differences in the physical properties of fruits having about the same size were probably due to environmental conditions in conjunction with the analytical methods used (Guil et al., 1998). In addition, moisture, crude protein, ash, crude fiber and crude oil contents and fatty acid compositions of seeds are affected mainly by variety and growth conditions. Carrot seed oil has a high content of petroselinic acid. Their high protein and oil contents along with their pleasant odor and taste suggest that this fruit can be of use in the food industry. Future studies could include amino acid contents, glucosinolates, sterol, tocopherol contents of carrot seeds and their oils. By-products of plant food processing represent a major disposal problem for the industry concerned, but they are also promising sources of compounds which may be used because of their favorable technological or nutritional properties (Schieber et al., 2001).

\section{ACKNOWLEDGEMENT}

This work was supported by Selçuk University Scientific Research Project (S.U.-BAP, KonyaTurkey).

\section{REFERENCES}

Adams R. 2001. Essential oil components by Quadrupole GC/MS. Allured Publishing Corp., Carol Stream, IL, USA.

Akgül A., Özcan M. 1999. Some compositional characteristics of capers (Capparis spp.) seed and oil. Grasas y Aceites 50, 49-52. 
AOCS, 1990. Official Methods and Recommended Practices. Vol.1. 4th edn.American Oil Chemists Society, Champaign,II.

AOAC, 1984. Official Method Analyses, 14th edn. Association of Official Analytical Chemists, Arlington, VA.

AOAC, 1990. Official Method Analyses, 15th edn. Association of Official Analytical Chemists, Washington, DC.

Bauer K, Garbe D, Surburg H. 1990. In commen Fragrance and Flavor Materials, preparation, Properties and Uses, 2nd edn, p142, VCH, Weinheim.

Baytop T. 1984. Treatment with plants in Turkey. İstanbul Univ. Publ. No. 3255, İstanbul. (in Turkish)

Cemeroğlu B, Acar J. 1986. Fruit and Vegetable Processing Technology (Publ.6). Turkish Association of Food Technologists, Ankara.

Chen, BH, Tang YC. 1998. Processing and stability of carotenoid powder from carrot pulp waste. J. Agric. Food Chem. 46, 2312-2318.

Clevenger Jl. 1928. Apparatus for the determination of volatile oil. J. Am. Pharm. Assoc. 17, 345-349

Çağlarırmak N. 2003.Biochemical and physical properties of some walnut genotypes (Juglans regia L.). Nahrurg/Food 47(1), 28-32.

Dutta PC, Appelqvist LAAD. 1989. The effects of different cultural conditions on the accumulation of depot lipids, notably petroselinic acid, during somatic embryogenesis in Daucus carota L. Plant Sci. Lime Rick 64, 167-177.

Dutta PC, 1992. Incorporation of $\left[{ }^{14} \mathrm{C}\right]$ acetate in different lipid classes and in the fatty acids of triacylglycerols in somatic embryos and cotyledon slices of Daucus carota L. Swedish Journal of Agric. Res. 22, 117-123.

Fritz D, Stolz W. 1989. Gemusebar, 9th edn., Ulmer, Stuttgart, pp 183-189.

Gonny M, Bradesi P, Casanova J. 2004. Identification of the components of the essential oil from wild corsican Daucus carota L.using 13C-NMR spectroscopy. Flav. Fragr. J. 19, 424-433.

Griffiths DW, Robertson GW, Millam S, Holmes AC. 1992. The determination of the petroselinic content of coriander (Coriandrum sativum) oil by Capillary Gas Chromography. Phytochemical Analysis 3, 250-253.

Guil JL, Gimenez JJ, Torija ME. 1998. Mineral nutrient composition of edible wild plants. J. Food Composition and Analysis 11, 322-326.

Gunstone FD.1991. The ${ }^{13} \mathrm{C}$-NMR spectra of six oils containing petroselinic acid and of aquilegia oil and meadowfoam oil which contain $\Delta 5$ acids. Chem. Phys. Lipids 58, 159-167.

Henn T, Kunz B. 1996. Pflanzliche Reststaffe zur herstellung von Functional Drinks. Flüssiges Obst., 63, 715-719.

Hışı Y. 1988. Instrumental Analysis Techniques (Eng. Fac. Publ. 55), Ege University, Bornova-İzmir. (in Turkish)

Hondelmann W. 1985. Das vorkommen einer ungewöhnlichhen Fettsaure, der petroselinsaure in der familie der doldengewachse als Ausgangspunkt für die entwicklung neuer ölfrüchte-Bestands-aufnahme und kritische würdigung. Landbauforschung Wölkenrode 35, 185-190.

İlisulu K. 1973. Oil Plants and Breeding. Çağlayan Bookshop, İstanbul.

Jasicka-Misiak I, Lipok J, Afarski PAD. 2002. Phytotoxic activity of the carrot (Daucus carota L.) seed oil and its major components. Journal Essent. Oil Bearing Plants 5, 132-134.
Kleiman R, Spencer GF. 1982. Search for New Industrial Oils: XVI. Umbelliflorae- Seed Oils Rich in Petroselinic acid. J.Am.Oil Chem.Soc. 59, 29.

Küsmenoğlu S, Toker G, Bașer KHC, Koca U. 1997. Composition of the fruit oils of Capparis species. Acta Pharm Turc. XXXXXX, 55-57.

Lafuente MT, Cantwell M, Yang SF, Rubatzky V. 1989. Isocoumarin content of carrots as conditions. Acta Hort 258, 523-534.

Lawrence BM. 1999. Progress in essential oils:carrot seed oil. Perfum. Flavour 24, 52.

Lawrence BM. In:Essential Oils 1992-1994, Allured, Carol Stream, IL. P. 28, ibid. 1988-1991, pp. 27 and 104, ibid. 1979-1980, p. 37, ibid.1976-1978, p2.

Lie Ken Jie MSF, Lam CC, Pahsa M. $1996 .{ }^{13} \mathrm{C}$ Nuclear magnetic resonance spectroscopic Analysis of the triacylglycerol composition of Biota orientalis and carrot seed oil. J. Am. Oil Chemist Soc. 73, 557-562.

Matthaus B, Özcan M. 2005. Glucosinolates and fatty acid, sterol, and tocopherol composition of seed oils from Capparis spinosa var. spinosa and Capparis ovata Desf. var.canescens (Coss.) Heywood. J.Agric. Food Chem. 53, 7136-7141.

Mazzoni V, Tomi F, Casanova J. 1999. A daucane-type sesquiterpene from Daucus carota seed oil. Flav. Fragr.J. 14,268-272.

Murphy DJ. 1993. Designer Oil Crops. Breeding, Processing and Biotechnology. VCH Verlagsgesellschaft Winheim.

Negi PS, Roy SK. 2000. Effect of low-cost storage and packaging on quality and nutritive value of fresh and dehydrated carrots. J.Sci. Food Agric. 80, 2169-2175.

Nilsson T. 1987.Carbohydrate composition during long term storage of carrots as influenced by the time of harvest. J.Hort Sci. 62, 191-203.

Ochocka RJ, Lamparczyk H. 1993. Evaluation of essential oils from the family Umbelliferae using principal component analysis. Pharmazie 48, 229-230.

Ohsawa K, Chinen C, Tajanami S, Kuribayashi T, Kurukouchi K. 1994. Studies on effective utilisation of carrot pomace. I. Effective utilisation to bread. Research Report of the Nagano State Laboratory of Food Technology 22, 22-28.

Ohsawa K, Chinen C, Tajanami S, Kuribayashi T, Kurukouchi K. 1995. Studies on effective utilisation of carrot pomace. I. Effective utilisation to cake, dressing and pickles. Res. Report of the Nagano State Laboratory of Food Technol. 23, 15-18.

Özcan M. 2004. Characteristics of fruit and oil of terebinth (Pistacia terebinthus L.) growing wild in Turkey. J. Sci. Food Agric. 84, 517-520.

Özcan M. 2005. Mineral composition of different parts of Capparis ovata Desf. var. canescens (Coss.) Heywood Growing wild in Turkey. Journal of Medicinal Food 8(3), 405-407.

Parker TD, Adams, DA, Zhou K, Haris M, Yu L. 2003. Fatty acid composition and oxidative stability of coldpressed edible seed oils. J. Food Sci. 68, 1240-1243.

Pinilla MG, Perez-Alonso MJ, Velasco-Negueruela AAD. 1995. Volatile constituents from fruits of Daucus carota L., subsp.gummifer Hooker Fil. J. Essent. Oil Res. 7, 433-435.

Püskülcü H, İkiz F. 1989. Introduction to Statistics. Bilgehan Pres, Bornova-İzmir, pp 333. (in Turkish)

Reiter B, Lechner M, Lorbeer E. 1998a. The fatty acid profiles including petroselinic and cis-vaccenic acid-of different Umbelliferae seed oils. Fett/Lipid 100(11), 498-502.

Reiter B, Lechner M, Larbeer E.1998b. Determination of petroselinic acid in Umbelliferae seed oils by 
automated gas chromotography. J. High Resol. Chromatogr. 21, 133-136.

Rühl G. 1993. Potentielle Industriepflanzen für die Erzeugung besonderer Fettsauren. Landbauforschung Völkenrode 43, 17-26.

Schaller RG, Schnitzler WH. 2000. Nitrogen nutrition and flavour compounds of carrots (Daucus carota L.) cultivated in Mitscherlich pots. J.Sci. Food Agric. 80, 49-56.

Schieber A, Stintzing FC, Carle R. 2001. By-products of plant food processing as a source of functional compounds recent developments. Trends in Food Science \& Technol. 12, 401-413.

Seher A, Gundlach U. 1982. Isomeric monoenoic acids in vegetable oils. Fette, Seifen, Anstrichm. 84, 342-349.

Seljasen R, Bengtsson GB, Hoftun H, Vogt G. 2001. Sensory and chemical changes in five varieties of carrot (Daucus carota L.) in response to mechanical stres at harvest and post-harvest. J. Sci. Food Agric. 81, 436-447.

Seljasen R, Hoftun H, Selliseth J, Bengtsson GB. 2004. Effects of washing and packing on sensory and chemical parameters in carrots (Daucus carota L.). J. Sci. Food Agric. 84, 955-965.
Simon PW. 1985. Carrot flavor: effects of genotype, growing conditions, storage, and processing. In: Evaluation of Quality of Fruits and Vegetables (ed. By Patte,H.E.), Avi Publ., Westport, CT, pp 315-328.

Skujins S. 1998. Handbook for ICP-AES (Varian-Vista). A short Guide To Vista Series ICP-AES Operation. Varian Int. AG, Zug, Version 1.0, Switzerland.

Staniszewska M, Kula, J. 2001.Composition of the essential oil from wild carrot umbels (Daucus carota L. ssp.carota) growing in Poland. J. Essent. Oil Res. 13, 439-441.

Thies W. 1993. Determination of the petroselinic acid content in seeds of Coriandrum sativum by Gas Liquid Chromatography. Fat Sci. Techno/ 95, 21-23.

TSE, 1971. Analysis Methods of Vegetable Oil. TS 894. Turkish Standard Institute, Ankara-Turkey (Türkiye).

Vogel, G. 1996. Handbuch des speciellen Gemulsebaus. Ulmer, Stuttgart, pp 958-959.

Zlatanov M. 1994. Untersuchungen über die Phospholipidzusammensetzung der Glyceridöle einiger vertreter der familie Apiaceae. Fat Sci. Technol. 96, 456-457.

Recibido: 10/11/06 Aceptado: 26/6/07 